\title{
The broken promises of the social investment market
}

\author{
David Harvie* and Robert Ogman ${ }^{\dagger}$
}

Forthcoming in Environment and Planning A: Economy and Space [accepted 7 January 2019]

\begin{abstract}
The United Kingdom is pioneering a new model for the delivery of public services, based around the device of a social investment market. At the heart of this social investment market is an innovative new financial instrument, the social impact bond (SIB). In this paper we argue that the SIB promises (partial) solutions to four aspects of the present multi-faceted crisis: the crisis of social reproduction; the crisis of capital accumulation; the fiscal crisis of the state; and, the crisis of political legitimacy. In this sense, we conceive the social investment market as a crisis management strategy.

We draw on evidence from the world's first social impact bond, the Peterborough SIB, launched in 2010, as well as from other SIBs, in order to assess the extent to which the social investment market delivers on its four promises. In doing so, we argue that the crisis of neoliberalism and the social investment market are not only in historical correspondence, but in a relation of causality to one another. In developing this argument, this paper contributes to contemporary theories of neoliberalism by investigating how concrete state developments and societal restructuring is being advanced around the idea of linking marketisation with progressive social change. It also supports critical practitioners by offering a theoretical lens to identify the contradictions of this increasingly popular policy approach.
\end{abstract}

\section{Keywords}

neoliberalism; crisis; financialisation; marketisation; social investment; social reproduction; Big Society; social impact bond; public services; probation services

\section{Acknowledgement}

We are grateful to Brett Christophers and three anonymous referees for their constructive comments. Responsibility for remaining weaknesses and omissions is ours.

\footnotetext{
* Centre for Philosophy and Political Economy, University of Leicester School of Business, Leicester LE1 7RH; david.harvie@,le.ac.uk.

${ }^{\dagger}$ Department of Politics and Public Policy, De Montfort University, Leicester; robert.ogman@gmail.com
} 


\section{Introduction}

A social impact bond (SIB) is an innovative new type of financial instrument, whose purpose is to align the interests of the commissioner of a public service (usually the state), the providers of that service, and financial investors who fund the service and profit if it meets target outcomes. The world's first SIB - designed to fund a probation service in Peterborough, a small city, $120 \mathrm{~km}$ north of London - was launched in Britain in March 2010. Since then, the 'social investment market' has grown, both within the UK and worldwide. As of January 2018, there were more than 100 SIBs in operation across the globe, totalling nearly $£ 300$ million (Pybus, 2018). Most SIBs are located in the US and UK, but they have also been enthusiastically embraced in other developed countries, such as Australia, the Netherlands and Israel; in the global South, Development Impact Bonds have been established. According to The Economist (2017) 'impact investing', once a 'niche product', is now 'inching into the mainstream'.

In Britain, support for the social investment market has been cross-party: changes in government in 2010 and (arguably) in 2015 and 2016 have neither blurred the vision nor interrupted its realisation. What has changed, however, is the discourse surrounding social impact investing. Conceived during the era during which history was said to have 'ended' (Fukuyama, 1992) - an era in which there would be 'no more boom and bust' - the social impact bond was born into a world reeling from the financial crisis of 2008, a world on the brink of the 'Great Recession' and austerity. In these new circumstances social investment went from being a policy designed to help those 'left behind' by capitalism's triumph to, in the eyes of its enthusiasts at least, a framework offering a full-spectrum response to capitalism's crisis.

Thus, at the Peterborough SIB's launch, David Hutchinson, chief executive of Social Finance, the intermediary that engineered the bond, suggested that social sector organisations 'will be incentivised to develop innovative interventions to tackle ingrained social problems'; thenJustice Secretary Jack Straw emphasised the potential of the bond to provide 'value to the taxpayer' (ibid.); Toby Eccles, Social Finance's founder and Development Director, predicted that it would offer 'excellent returns on investment' (Ministry of Justice, 2010; Macdonald, 2010, quoted by Nicholls and Tomkinson, 2015: 344). We find similar claims echoed in the report of the G8's Social Impact Investment Taskforce (SIIT), established in 2013. Frequent references to 'hard-to-address' social problems and the need for 'innovative' solutions appear alongside acknowledgements of the difficulty of governments funding 'the sort of prevention initiatives that involve up-front public spending but do not deliver cost savings for many years' and the promise that investors will gain 'a new set of attractive investment opportunities' (SIIT 2014: pp. 14 \& 20).

These claims constitute our point of departure in this paper. Our first objective is to develop the argument, proposed by Dowling and Harvie (2014), that social investment can be understood as a form of 'crisis management', involving a set of promises to address at least three aspects of the multi-faceted crisis of neoliberalism. First, what we can term a crisis of social reproduction, that is, a crisis in the ability of individuals and communities to reproduce themselves and their livelihoods, a crisis which manifests itself in the specific problems identified by the social investment pioneers: youth unemployment, incarceration, homelessness, 'social exclusion'. Second, a fiscal crisis of the state (O'Connor, 1973) or state crisis (Peck, 2013), whereby levels of public debt are considered by policy-makers to be 'too high', necessitating a politics of austerity. Third, a crisis of capital accumulation, in which ongoing concerns about the global economy mean a dearth of profitable investment opportunities for capital and frequent 'flights to safety'. We suggest that, as well as promising to address these three crises, social investment also promises to offer a (partial) solution to capitalism's crisis of legitimacy. 
The paper's second objective is to describe the operationalisation of this strategy in the specific case of the Peterborough SIB. That is, we test the claims of David Hutchinson, Jack Straw and Toby Eccles, quoted above. Did the Peterborough SIB stimulate an innovative response to the problem of recidivism? Did it ease demands on the public purse? Did it generate financial returns for investors? And - finally - might the project have contributed to a relegitimisation of capitalism? We focus on the Peterborough bond because its status as the first such bond means that it is often treated as a benchmark. Moreover, with no other SIBs launched until 2012 - a full two years later - it remains the bond about which most information is publicly available; our evidence is obtained via readings of such published reports and documents.

We do not claim that the Peterborough bond is necessarily representative. We do, however, draw on evidence from other SIBs and we find that this evidence supports many of our conclusions. The caveat in fact draws attention to a feature of the social investment market that makes it of interest to geographers as well as political economists and scholars of finance. On the one hand, this market is being promoted at a national and even international level - by national governments, the G8's taskforce and the global 'Steering Group', non-governmental or quasi-governmental boosters and enablers such as Social Finance and Big Society Capital (the UK's social investment wholesale bank) - and most investors have similarly national or international reach. On the other hand, individual SIBs are themselves specific to local geographies. Indeed, the Localism Act, passed in 2011, did much to facilitate the SIB model and the Department for Communities and Local Government has played an important role in developing the policy, with the commissioners of SIBs frequently being local authorities. Discussing the US context Lake (2015) has described this as the 'financialization of urban policy'.

There are tensions between the concrete specificities - both spatial and sectoral - of individual SIBs and the social needs they purportedly address, on the one hand, and the universalising logic of finance and capital, on the other. It is too early to tell how or whether such tensions will be resolved and, by the same token, it is too early to judge the generalisability of our analysis of the Peterborough SIB. As Tse and Warner (2018) argue, SIBs can produce diverging outcomes based on historical and geographical contexts; they are the outcomes of 'actually existing struggles' (Williams et al., 2014: 2798) on this terrain, between protagonists with 'competing value regimes' (Harvie et al., 2018).

\section{Concepts and actors}

We begin by explaining the mechanics of the social impact bond, before, in the next section, providing a brief account of its genesis. The SIB is not a conventional bond, which pays a fixed 'coupon' (except in the case of default). Rather it is a type of 'structured product', a financial asset in which cash flows are dependent upon some underlying index or other metric. In fact, the SIB is a form of outcomes-based or payments-by-results $(\mathrm{PbR})$ contract. It is designed to mediate the relationship between, and align the interests of, three actors (or sets of actors). First, a commissioner, usually part of the state, which defines a set of social outcomes which it desires to see. Second, a service provider, tasked with the responsibility of delivering these outcomes. Third, a financial investor or investors, whose investment will fund the service. If, at the end of the contract period, the commissioner-defined outcomes have been met (i.e. if the intervention or the service has been successful), then the investor(s) will receive a financial return; if the outcomes are not met, then no dividend will be paid and investors may lose their initial investment. Dividends are paid by the commissioner (the state), but since it only pays for effective interventions, which are presumed to produce cost savings for the state, the value-formoney of public spending should be improved. The (financial) risk associated with 
unsuccessful interventions is meanwhile transferred to private investors. At the same time, because the focus is on social outcomes (as opposed to inputs or outputs), the model is supposed to drive innovation and diversification in the delivery of public services. (See Centre for Social Impact Bonds, nd.)

A fourth set of actors includes bodies such as Social Finance and Big Society Capital. These organisations support the social investment market, providing advice to and intermediation between the other key actors. Perhaps more controversially, they also act as champions for social investment (and social finance), promoting its benefits to policy-makers and society more generally. We engage with this discourse, along with the work of scholars who are generally enthusiastic about social investment, in what follows.

\section{History}

What we call the 'pre-history' of SIBs stretches back several decades, to the period of what Steger and Roy (2010: 50) call 'second wave neoliberalism'. From the late 1980s onwards, the destabilising effects of the radical market deregulation led by Thatcher and Reagan was giving way to a set of initiatives under the idea of the Third Way (Giddens, 1998), which sought to reconcile an acceptance, even embrace, of markets and their wealth-creating potential, with a commitment to social justice. This 'roll out neoliberalism' (Peck 2012), which sought to respond to the instabilities of 'first wave' neoliberalism, expanded market rule through organisations of civil society, the 'social economy', and the production of 'social capital'. Within this framework, which informed the policies of the Clinton administration in the US and Blair's New Labour project in the UK, 'welfare' and social spending were reconceptualised as social investment, that is, not as 'safety net' or protections from the vagaries of the market, but as a productive factor of market growth. Giddens (2000: 52), for example, argued that the welfare state must be reconstructed as a 'social investment state'.

At the same time, scholars were pondering how to harness the power of markets and selfinterest for the benefit of the poor as well as the rich. One such scholar was New Zealand economist Ronnie Horesh. His proposed mechanism for 'channel[ling] self-interest into solving social problems' was what he called the social policy bond: these he defined as 'bonds which are redeemable only when the government objective in question has been achieved' (Horesh, 1988: $267 \&$ 269). Although social policy bonds, as specified by Horesh, have never been issued, social impact bonds share many of their features. In 2000, the UK government created a Social Investment Task Force (SITF). This heralded the establishment of further task forces, numerous commissions and a variety of institutions, all oriented towards the development of a social investment market. Government White Papers, Bills and Acts followed, culminating with the launch, in 2010, of Big Society Capital, the UK's 'social investment wholesale bank', and, later in the same year, the Peterborough SIB, the world's first social impact bond (Dowling and Harvie 2014; Harvie, 2019).

Framed as a way of 'solving social problems at their root', in this case high levels of recidivism of short-term prisoners, the Peterborough SIB was commissioned by the Ministry of Justice (MoJ). The six-year (as conceived) probation project targeted male prisoners, serving sentences of less than 12 months sentences at Her Majesty's Prison Peterborough (Ministry of Justice and Social Finance 2010: 1). The bond was designed and managed by Social Finance, which acted as intermediary between the commissioner (the MoJ), financial investors and the service providers. Social Finance also purpose-created the One Service to manage a consortium of criminal-justice and prisoner charities, including St Giles' Trust, the Ormiston Trust, the YMCA and SOVA providing probationary services. There were 17 investors, who together 
contributed up-front capital of $£ 5$ million; these were all charitable foundations including Barrow Cadbury Trust, Esmée Fairbairn Foundation, Friends Provident Foundation, Panahpur Charitable Trust and the Tudor Trust. The One Service worked with three cohorts of approximately 1000 ex-offenders. Outcome payments for the investors were dependent upon measurable reductions in reoffending, relative to a UK-generated control group: these repayments would be triggered by a fall in 'reconviction events' of $10 \%$ or more for any one of the three cohorts, or of $7.5 \%$ for the entire group of 3,000-odd individuals.

Linking decarceration to government cost savings, the MoJ anticipated total possible savings of 'between $£ 44 \mathrm{~m}$ and $£ 90 \mathrm{~m}$ ' (Ministry of Justice, 2014). If the target reduction in reconviction events was met then investors could expect returns on their investment of around $7.5 \%$ and possibly rising to $13 \%$, depending on the level of reductions (Disley and Rubin, 2014: 12-13), with the total outcome payments capped at $£ 8$ million. Investors' returns would be paid by the MoJ, together with the Big Lottery Fund (BIG). If the targets were not reached investors would risk losing their capital, and the government would not have funded an 'ineffective' programme. As Alec Fraser et al. (2018, p. 10) explain, this was meant to 'transfer risk from the public sector to the private sector' - in other words, to 'privatize the risks and share the gains'. The idea is to embed economic activities in practices of societal benefit, transcending the narrow idea that 'the business of business is business' alone (Friedman, 1970), as well as the practice of 'corporate social responsibility' based on 'firms voluntarily assuming responsibility for their externalities' (Crouch, 2006: 1533).

In April 2014, the Ministry of Justice announced the premature termination of the Peterborough SIB. In its place it launched a national probation programme, Transforming Rehabilitation; this included all short-term offenders and hence eliminated the Peterborough bond's control group (Social Finance, 2014). The SIB funding structure continued until the end of the second cohort; for the third cohort, a traditional fee-for-service arrangement was adopted.

To avoid conceptual overload it is worth clarifying the key concepts. Social investment, when applied to government spending, refers to the idea, associated with the Third Way, that such spending should be understood as an investment, leading to concrete economic benefits to individuals and society more broadly. When applied to the private sector, the term designates the practice whereby investors are concerned not only with financial returns, but also with social returns or social impact (hence social investment's associated strapline doing well by doing good). Unless stated otherwise, it is in this second sense that we use the term in this paper. We understand social investment to be synonymous with the term impact investment, as in the name of the G8's taskforce and the title of its subsequent report, Impact Investment: The Invisible Heart of Markets (SIIT, 2014). The practice of social investment is an element of the wider field of social finance, which also concerns itself with ethical investment, social entrepreneurship, cooperative and mutual finance and 'philanthrocapitalism', amongst other practices (Nicholls et al., 2015). Social Finance (capitalised) is also the name of an organisation founded in 2007 to support and champion various social finance practices, including social investment. (As we have noted, the Peterborough SIB was designed by Social Finance.) We use social investment market to designate that set of actors - and their actions - who are involved in social investment. Finally, the social impact bond, a term coined in 2008 by the Young Foundation, is the key financial instrument at the centre of this market (Nicholls and Tomkinson, 2015: 343). In the United States SIBs are also known as Pay-for-Success bonds; in Australia they are Social Benefit Bonds.

\section{Theories and critique}


There is a now growing body of literature more critical of the social investment market and social impact bonds. This literature engages scholars from a variety of disciplinary backgrounds - including accounting, finance, geography, political economy and sociology - and is written against the backdrop of several economies. Rather than attempting to review it in depth, in the following paragraphs we note the several (complementary and overlapping) lines of critique that have emerged. One concerns the 'boundaries' between the 'public' and the 'private'. Sinclair et al. (2014), for instance, argue that SIBs represent a 'boundary shift', altering the 'moral character' of welfare services. These authors also raise the thorny issue of the quantification and measure of outcomes, as do Berndt and Wirth (2018), pointing out that 'social outcomes are notoriously difficult to measure' and raising concerns about 'unintended consequences ... result[ing] from perverse incentives' (McHugh 2013: 249 \& 250). A Guardian report on the Peterborough SIB, soon after its launch, noted that '[m]easuring reoffending rates is notoriously complicated', and quoted the general secretary of the Prison Governors' Association as warning those running the scheme "not to "cherry-pick" the least difficult offenders and leave the hardline cases to the prison and probation services' (Travis, 2010).

A second broad line of critique concerns the role of the state in the making of the social investment market and the relationship between social investment and neoliberalism - see, for example, Dowling and Harvie (2014); Williams et al. (2014), Harvie (2019) and, again, Berndt and Wirth (2018). Several authors understand the social investment market through the lens of financialisation, warning - since financialisation is taken to be a normative bad - of a 'financialisation of the welfare state' (e.g. Dowling 2017) or of a 'financialisation of social reproduction' (Harvie, 2019), in which social policy goals - and social needs - become subject to financial market discipline. Relatedly, Cooper et al. (2016) adopt a Foucauldian approach, emphasising SIBs' neoliberal and biopolitical rationalities. In the next section we unpack the concept of social reproduction and explore the way in which the social investment market can be understood as response to a crisis of social reproduction.

Lake (2015) also adopts the lens of financialisation, but focuses on urban and municipal governance (in the US). His contention is that urban policy is being subordinated to financial logics, producing 'a radical realignment of ends and means'. That is, rather than financial tools being employed in order to meet social goals, the attainment of social outcomes has become the means towards the end of a financial return. In a similar vein to Lake, Rosenman (2017) highlights the 'geographies of social finance', drawing our attention to the spatial as well social distance between investors and the 'targets' of their investment: there are, she reminds us, 'no SIBs devoted to reducing white-collar crime' (p. 6). Rosenman also emphasises the uneven distribution of risk between investors and 'beneficiaries', and between the various 'sites of investment': that investors bear financial risk is a well-known feature of the SIBs, but the 'social repercussions of the failure to achieve intended outcomes' are excluded from the risk model ( $p$. 8). We certainly find such 'distance' and uneven distribution of risk in our study. Most of the investors in the Peterborough SIB - we named some in the previous section - have 'fashionable' London addresses and none is based in Peterborough. And, as we explain later in the paper, these investors received a financial return despite the mixed results of the probation scheme enabled by the Peterborough SIB and the absence of 'cashable savings' to the public purse.

In the sections that follow, we consider the articulations between the social investment market, on the one hand, and the four crises - crisis of social reproduction, fiscal crisis of the state, accumulation crisis, legitimation crisis - on the other. We frame the social impact bond as part of a crisis management strategy. By this we mean the way certain political actors intervene into our current disrupted political-economy with the intention of (re)shaping the 'contours, forms, norms, procedures and practices' of the state and society and thereby 'impos[ing upon them] a 
developmental trajectory' (Hay, 1999: 331). Such interventions advance when they are able to achieve a 'consensus on interpretations about a crisis (or crises) and its (or their) most salient features', and furthermore, determine 'private and public strategic and policy initiatives to manage the crisis and/or move beyond it' (Sum and Jessop, 2013: 404-405). Such strategies are not 'arbitrary, rationalistic, or willed' (Gramsci); instead they correspond in important ways to objective possibilities within a given societal structure and represent a contingent 'spatiotemporal fix' (Harvey, 2003: 115). These strategies do not (necessarily) resolve the crises often they merely displace them - and outcomes are, of course, dependent upon actions and struggle understood most broadly. It is the 'correspondence' between the crisis/es of neoliberalism and social investment as 'crisis management strategy' upon which we build our argument that social investment is linked to neoliberalism's crisis in a causal rather than a casual way.

\section{The crisis of social reproduction}

Throughout the three volumes of Capital, but particularly in part 7 of Volume 1, on 'the accumulation of capital', and the reproduction schema of Volume 2, Marx discusses the way in which the capitalist mode of production is reproduced. In recent decades however, Marxist feminists have repurposed Marx's category of social reproduction in order to explore the way in which labour-power, Marx's 'special commodity', is reproduced - an aspect of capitalism seriously neglected by Capital's author. As Cindi Katz (2001: 711) explains,

\footnotetext{
Social reproduction encompasses daily and long term reproduction, both of the means of production and the labor power to make them work. At its most basic, it hinges upon the biological reproduction of the labor force, both generationally and on a daily basis, through the acquisition and distribution of the means of existence, including food, shelter, clothing, and health care. According to Marxist theory, social reproduction is much more than this; it also encompasses the reproduction of the labor force at a certain (and fluid) level of differentiation and expertise.
}

Much of this scholarship has sought to analyse the developing entanglements, tensions and contradictions between production, on the one hand, and social reproduction and its close cousin care work, on the other (see, for instance, Dalla Costa and Dalla Costa, 1999; Barbagallo and Federici, 2012; N. Fraser, 2016). Nancy Fraser (2016: 103-4) distinguishes 'at least three regimes of social-reproduction-cum-economic production in capitalism's history': first, the $19^{\text {th }}$-century model of 'liberal competitive capitalism', in which workers mostly reproduce themselves 'autonomously' from capital; second, the 'state-managed capitalism of the $20^{\text {th }}$ century', characterised by state and corporate provision of social welfare; third, 'the globalizing financialized capitalism of the present era', in which both state and corporations have disinvested from social welfare, externalising care onto families and communities.

The retrenchment of welfare services in the 1980s - signalling the end of Fraser's second regime - was accompanied by the growth of the 'social sector' to fill the gap. As civil society assumed more responsibility for addressing the breakdown of social reproduction we also witnessed an extension of market logics in both the public and social or 'third' sectors. Examples include: the emergence of social enterprises; the outsourcing and privatisation of public services; the introduction of New Public Management, which introduced business practices into government administrations; and, more generally a shift 'from government to governance' (Alcock and May, 2014: 291-293; Boyer 1990). Nicholls and Tomkinson (2015: 340) accurately situate social impact bonds within this trajectory, noting their 'strong focus on reforming state bureaucracies and dismantling centralized government systems and structures in favour of more "business-like" and enterprising models of welfare service delivery and internal operations'. This transition from the second to the third regime of social reproduction 
also corresponds to the shift from welfare state to 'social investment state': as we noted earlier, this was theorised by Anthony Giddens and is linked to the project of the 'Third Way'. In fact, social investment's enthusiasts have seen it as a response to the rising inequality associated with neoliberal, financialised capitalism and identified by Fraser. Under the governments of Clinton in the US and Blair in the UK, this social-investment or Third-Way perspective underpinned a prioritisation of 'labour-market activation', that is, policies targeting latent and future labour-power. Flagship policies included No Child Left Behind in the US and Sure Start - along with Blair's mantra of 'education education education' - in the UK.

In the wake of the financial crisis of 2017-8, social problems have become more pronounced, a result of falling wages, job loss, increasingly precarious employment relations, rising cost of living, compounded by the further hollowing out of welfare services for those most in need (Farnsworth and Irving, 2015; O'Hara, 2015). Mere concern with rising inequality has given way to a more foreboding discourse, from the 'quiet crisis', identified by then-Labour leader Ed Miliband in 2011, 'that is unfolding day by day in kitchens and living rooms in every town, village and city up and down this country' (Miliband, 2011), and then-prime minister David Cameron's diagnosis of 'broken Britain', to the 2016 discovery by Theresa May (Cameron's replacement) of the 'JAMs' - 'just about managing families'. But many families and individuals in the UK are not managing at all. In November 2018, the United Nations' special rapporteur on extreme poverty and human rights published a damning report, concluding that ' 14 million people, a fifth of the population, live in poverty. ... 1.5 million are destitute, unable to afford basic essentials. ... For almost one in every two children to be poor in twenty-first century Britain is not just a disgrace, but a social calamity and an economic disaster, all rolled into one' (Alston, 2018: 1). This is what Nancy Fraser (2016) and Brown et al. (2013) - along with others - have described as a 'crisis of social reproduction' and a 'crisis of care'.

The growth of the social investment market over the last decade may be seen in the context of this social crisis. One policy response was the 'Big Society' (Dowling and Harvie, 2014: 7), launched by Cameron in 2010 and designed to decentralise responsibility away from a supposed 'big government' model and towards 'voluntary action and social enterprise' as the way to "promot[e] improved social inclusion and "fixing Britain's broken society" (Alcock 2012). It quickly became clear, however, that the lack of resources for localities, communities and families hampered their capacity to adequately respond. The New Economics Foundation (2013: 57) reported that the 'Big Society [was] thwarted by the combined effects of recession, public spending cuts, and welfare reform'. Big Society Capital, the government-founded 'social investment bank', and SIBs, are meant to fill this funding gap, supposedly bringing with them the command over social wealth that money represents and which was lacking in the Big Society model.

For its proponents, however, the social investment market model promises more than financial resources. It promises to solve 'society's most intractable social problems' (Travis, 2010) among them poor mental health, homelessness, unmet childcare and education needs and, as we see in the case of Peterborough SIB, high levels of incarceration - and, in this sense, social investment can be understood as a strategy of managing the crisis of social reproduction. According to Alec Fraser et al.'s (2018: 10) review of the literature, such an argument 'is frequently articulated in UK government publications, which particularly stress the potential virtues of SIBs by emphasizing how they may foster innovation, and prevent or ameliorate complex social problems'. Key here is 'social innovation', which is enabled as a result of shifts from a 'bureaucratic' to a business model of service-delivery and, importantly, in values and practices such that service providers are judged not on the 'level' or 'quality' of their service, but on quantifiable 'outcomes' or 'impact'. In addition to their narrow focus on measurable outcomes - a reduction in truancy or 'reconviction events', say - proponents of the social- 
investment model frequently presume that the charities and social enterprise who deliver the services under a PbR contract or SIB are capable of significantly improving social 'outcomes' through facilitating personal behavioural changes in their users or 'clients'; obscured is the impact of radical market-based policies, often decided at geographical scales far removed from the problems, which have exacerbated inequality and poverty.

Turning now to the Peterborough SIB, that project sought to reduce high levels of reincarceration, advancing the Ministry of Justice aim of 'breaking the cycle'. According to the MoJ (2014), 'around 60\% of adults who enter jail on short-term sentences (less than 12 months) will go on to re-offend within a year of release'. One cause of this cycle is socio-economic. Social Finance (2011: 6) has acknowledged this, noting for instance that short-term offenders 'leave prison with typically $£ 46$ in their pocket, often with nowhere to live, no job to go to and no family waiting for them'. Yet, rather than targeting these socio-economic causes, SIBs often bracket them out, naturalising them as mostly immutable elements of the political-economic context; 'interventions' are instead limited to filling service gaps in the expectation of improving the efficacy of ex-offenders' personal coping strategies.

This shift in focus from social causes to individual failures is by no means peculiar to the Peterborough case. It reflects a broader shift since the 1990s towards New Public Management, with its emphasis on technocratic and managerial styles, and behaviourist methods in social work to address personal rather than systemic failures. As a World Economic Forum (2013: 19) report suggests, SIBs seek to solve social problems by individual solutions: the SIB funds 'an intervention to address a social challenge, typically related to behavioural change'. Hence, we see in the Peterborough case, the 'subdivision' of ' $\mathrm{t}] \mathrm{h}$ he overall social context [...] into specialized policies to dis-identify societal interrelations and changes, and to individualize the problems of social groups' (Candeias, 2011: 2; quoted in Brand, 2013: 436).

Having bracketed out possible socio-economic factors, the Peterborough project sought to reduce recidivism by providing a bespoken 'through the gates' service to ex-prisoners. 'Community resettlement' would be sought by relying on family support, 'benefits and financial advice', and work training (Social Finance, 2011: 9), but also busying activities (e.g. 'litter picking', fishing, and baking) to 'reduce idleness' (Ogman, 2018b). One case worker succinctly described their job as 'put[ting] in a strong coping strategy for the client' (Disley et al., 2015: 31). They sought to 're-able' individuals to cope with, rather than ameliorate, strenuous circumstances. This reflects an increasingly popular conception and practice of 'resilience' in the UK which is 'highly agent-centric' in its 'appli[cation] to how individuals and households respond to hardship' (Dagdeviren et al., 2016: 1). It has a longer history in the 'social capital' tradition of managing (structural) social problems (Burmester and Wohlfahrt, 2015).

We see this scalar mismatch in many SIBs: socio-economic or structural causes are identified as being behind a given social crisis, yet the proposed interventions focus on personal behavioural changes. Another example is the first US SIB, a project, inspired by the Peterborough SIB, to reduce re-incarceration among adolescents in New York City's notorious Rikers Island jail. As Ogman (2018a) shows, the intervention relied solely upon group therapy methods, despite practitioners' regular observations to the contrary that poverty and racial profiling are at the root of the city's high incarceration levels. The effort 'to restructure distorted thinking and perceptions' and thereby 'change a person's behavior for the better' (Rudd et al., 2013: 29) had no 'impact' upon recidivism, and the project was subsequently terminated prematurely in 2015 (Parsons et al., 2016). 
In Peterborough however, Social Finance (2017) could announce in July 2017 a 9\% reduction in reoffending and the 'success of the first ever Social Impact Bond'. Reductions were 8.4\% for the first cohort and $9.7 \%$ for the second, both below the $10 \%$ target for a single cohort, but above the $7.5 \%$ target for the project as a whole. As we noted above, the project was cancelled before the third and final cohort received its 'intervention'; in the final evaluation the impact for this third cohort was imputed. The success of the SIB ensured investors received returns of 'just over 3\% per annum for the period of investment' (Social Finance, 2017; Anders and Dorsett, 2017). Yet this outcome was hardly a surprise. Despite claims of social 'innovation', the One Service had merely modified an existing St Giles project of individualised services and through-the-gate support, and applied it to a new population group, short-term offenders, which had previously lacked any support whatsoever (Disley et al., 2011: 3). The approach adopted also aligned with theory and evidence from desistance studies (Disley et al., 2015: 54). Moreover, the particular set of interventions could easily have been financed via conventional models, a point acknowledged by a Ministry of Justice-commissioned report (ibid: 53).

Turning to other examples, in their study of the London Homelessness SIB, for instance, Cooper et al. (2016) report that although there was some 'innovation in practice' - the adaptation of the so-called Navigator Model - this turned out to be 'impossible to operationalize, for financial and practical reasons'. They also offer a vignette that is possibly worrying for what it reveals about the way 'social innovation' might occur: a service-provider interlocutor tells them that 'the initial business case contained the "kind of ideas that a non-expert on homelessness would come up with" and that the outcomes became more realistic after negotiations had taken place' (pp. 70 \& 71). In another study, Harvie et al. (2018) interviewed an investor in several UK SIBs, discovering that this investor was reluctant to back truly innovative interventions, preferring to stick with tried-and-tested methods; a service provider interviewed as part of the same study concurred with this view. Drawing on evidence from the UK and the US, Berndt and Wirth (2018: 33) suggest there is a 'tension between creative experimental play and standardization', noting both that '[a]t the end of the day, the issuing government agency has a strong influence on the project design' and that 'a large number of SIBs do not really test innovative anti-poverty approaches but apply intervention formats that already have a positive track record'.

This reliance on 'tested and tried' solutions is little surprising given that it is risky from the investor's point of view to invest in organizations that apply untested interventions (Callanan et al. 2012: 7). This inherent bias towards established solutions puts limits to the seemingly experimental character of SIBs, having a standardizing effect and stifling the very 'innovative' character of the instrument that protagonists are celebrating in their representations. (Berndt and Wirth 2018: 33)

Hence, Warner (2013: 304) implies, intriguingly, that social innovation does not occur, when she writes: 'How do SIBs work? First, you need an intervention that has been tested and proven to provide a certain rate of success.'

But the marginal effect of SIBs, and their limitation to certain localities within narrow time frames, has not prevented SIBs from becoming used on a higher scale for political ends. Just days after the release of second-cohort figures for the Peterborough project, Gordon Brown (2017) heaped praise on the project for the general lessons that political leaders should take from it, writing that it 'thoroughly transforms our view of what is possible' and has 'become the guiding light for hundreds of millions of dollars in investment in social reform'. Anticipating an argument we develop in our final substantive section, we claim therefore that the SIB is used to address legitimacy problems, and not just social problems of local significance. It was scaled up symbolically and practically to the levels of the national state, 
and even internationally, as Wiggan (2018: 721) writes, for the 'financialised reconfiguration of the welfare state as the route to a better society'.

There is a large discrepancy between minor improvements and the grand narrative of 'social change' under whose banner the social investment market is being rolled out. While we believe it possible for such narrowly designed 'preventative services' to achieve similar successes in other localities, we also see little reason to expect such projects to achieve more than marginal success in those places. Similar to work-activation or 'workfare' programmes, the Peterborough and other SIBs appear to have only minimal powers to relieve social crises. As Peck (2001: 347) explains, 'success' is often limited to people 'already nearest the front of the employment queue' and those who are 'the most job-ready'. In the area of criminal justice, we agree with Mills and Roberts (2012) that 'breaking the cycle of incarceration' requires 'looking beyond criminal justice'. Such a shift would move from poverty management towards poverty alleviation, but such approaches, while popular in society, have not resonated politically during the first decade since the financial crisis.

\section{The fiscal crisis of the state}

The crash of 2007-8 has had many repercussions. Of interest to us here is the way in which a collapse in state revenues along with enormous public bailouts of 'too-big-to-fail' financial institutions transformed a private debt crisis into a (threatened) sovereign debt crisis. The need to avoid such a sovereign debt crisis - 'going the way of Greece' - was in turn used to justify austerity. According to Konzelmann's (2014: 724-5) account, while initially,

$[\mathrm{P}]$ rominent economists and policy makers rekindled Keynesian ideas about the stabilising role of fiscal deficits[, ...] by early 2009 the consensus among economists began to crumble. ... [I]n 2010, with the imminent depression apparently averted but with unemployment still high, policy was sharply reversed as concern about high levels of public debt led to calls for fiscal austerity, first in the eurozone (due to the perceived risk of sovereign debt default by weaker members) and then worldwide.

Despite many economists and even policy-advisors such as the IMF questioning austerity and calling for fiscal stimulus, many governments, notably the UK's, continued to cut public spending. These cuts have been severe: between 2009-10 and 2012-13 UK central government spending on the delivery and administration of public services fell by $£ 41$ billion or $10.1 \%$; a further $£ 4$ billion was cut between 2012-13 and 2016-17. In per capita terms, the cuts have been even harsher: a 15.5\% reduction between 2009-10 and 2016-17 (Institute for Fiscal Studies, 2017). Following then-Chancellor George Osborne's autumn budget statement of 2014 - in which he announced that 60 per cent of the cuts were still to come - Norman Smith, Assistant Political Editor at the normally staid BBC suggested that,

[W]hen you sit down and read the Office for Budget Responsibility report it reads like a book of doom. It is utterly terrifying, suggesting that spending will have to be hacked back to the levels of the 1930s as a proportion of GDP. That is an extraordinary concept, you're back to the land of Road to Wigan Pier. (Swinford, 2014.)

Thus as Konzelmann (2014: 229) concludes:

At present the neoliberal orthodoxy remains unshaken, buttressed by the new dogma that the real problem is too much debt and that austerity (especially on the part of government) is required to get it down, a view that is being reinforced by the considerable economic and political influence of globalised financial markets.

We understand social investment - and its sudden rise in the post-2008 era - as a political response to this 'fiscal crisis of the state' (O'Connor, 1973). We have already noted that the 
report of the G8's Social Impact Investment Taskforce acknowledges that it is hard for governments to fund social projects that require 'up-front public spending but [which] do not deliver cost savings for many years'. The same report emphasises social investment's promise of helping governments 'fulfil [their responsibilities] more effectively' 'in a context of fiscal constraint' (SIIT, 2014: 14 \& 1-2). Elsewhere a J.P. Morgan report suggests that governments 'can counteract fiscal consolidation with impact investment' (Saltuk, 2011: 2), a view echoed by the authors of a report published by The Wilberforce Society (Ellis and Lubin, 2015). Warner and Clifton (2013: 55) similarly argue that SIBs enable 'constrained city leaders to try to provide basic services in a time of austerity' by 'raising private revenue'.

Our reading of the social-investment literature suggests that most of its advocates, outside of government at least, take a neutral position vis-à-vis austerity. While we have found no examples of proponents actively endorsing fiscal austerity, nor do we find any instances of contestation. Rather, most of those promoting the social investment market seem to have succumbed to what Davies and Blanco (2017) describe as 'austerian realism'. For some charities and other third-sector organisations, however, 'SIBs may offer them strategic opportunities to innovate, collaborate, and capitalize upon the changed economic and policy context following the banking crisis of 2008 and subsequent public spending cuts' (A. Fraser et al., 2018: 10)

Social impact bonds' promise to alleviate the state's fiscal crisis is three-fold. First, up-front expenditure is made by private investors, as opposed to the state. (The so-called private finance initiative - PFI - a controversial form of public-private partnership whose use became widespread under New Labour, achieved the same result, moving costs 'off balance sheet'.) Second, SIBs are structured such that investors only receive payments if projects are successful, that is, the state only pays for effective interventions. Third, SIBs are supposed to foster innovation in the delivery of public services, thus making service-delivery more cost-effective.

These logics underpinned the Peterborough SIB: private investors' up-front investments in probation services would not only make up a public sector budget shortfall in the present, but also reduce future expenditure. As a Rand report for the Ministry of Justice explained, 'the SIB model is based on the premise that the interventions funded will deliver cashable savings to government within the period of the bond', with 'a proportion of these savings [being] paid back to the investors' as return on capital (Disley et al., 2011: $8 \&$ 1). The MoJ calculated overall savings of 'approximately $£ 44 \mathrm{~m}$ ', possibly rising to $£ 90 \mathrm{~m}$ 'should the scheme produce a higher than anticipated reduction of re-offending' - up to 18 times the initial $£ 5$ million investment (Ministry of Justice 2014)! As we have explained, SIBs require measurable outcomes. In the case of the Peterborough SIB this led to the equation of reduced recidivism with a fall in 'reconviction events', specifically 'the number of times an offender is reconvicted in the 12 months following release from prison [... a measure that is] more closely linked to the costs [and therefore to potential savings] to the criminal justice system than the number of offences committed' (Cave et al., 2012: i-ii).

The Peterborough SIB did attract new resources to fund the probation project - the $£ 5$ million advanced by the seventeen social investors. But the One Service's success in reducing recidivism did not result in the anticipated savings to the Exchequer. As early as 2011, the Rand report warned, '[t]he SIB at HMP Peterborough is not likely to result in substantial cashable savings [monetized benefits] to the Ministry of Justice or other government departments' (Disley et al. 2011: 8; emphasis in the original); this negative projection was not revised in any later documents. The report's authors suggested that the project was 'too small' to effect overall government expenditure, but suggested that scaled-up projects might succeed in this regard. We see here a central contradiction in the SIB's rationale, for the project's failure to convert 
anticipated (or 'theoretical') savings into actual ('cashable') savings did not absolve the government of its contractual obligation to repay investors (capital plus 'dividend') in the case of the project achieving its recidivism-reduction outcomes. In other words, following Ogman (2016), if the Peterborough SIB in fact achieves social impact, it will not reduce government expenditure as promised, but in fact expand it, channelling public money through the social sector into the hands of private investors.

In fact, this unhappy possibility is what came to pass. The Peterborough project achieved its target outcome and thus produced 'social impact', but it produced no corresponding cashable savings from which investors could be repaid. In the event the MoJ paid $£ 3$ million of the total $£ 8$ million outcomes payments (returned capital plus dividend) received by investors, whilst the Big Lottery Fund (BIG) contributed the remaining $£ 5$ million. While the city of Peterborough benefitted from the initial financial infusion, overall the net public-fiscal effect of the SIB was negative, since the source of BIG's income is lottery-ticket sales, purchased by the public. In other words, the promise of this particular SIB was inverted. Instead of private actors filling a public funding gap, the government - and lottery-ticket-buying citizens - was now 'fill[ing] the funding gap for UK social impact bonds', as one newspaper reported (Pybus, 2012).

Pilot projects often encounter problems and require rethinking, but there appears to have been little reflection about this problem. As we describe below, we expect such 'mistakes' to reoccur. We have already quoted A. Fraser et al. (2018: 10) explaining that a central claim of the SIB is its ability to "transfer risk from the public sector to the private sector ... [to] privatize the risks and share the gains'. The Peterborough experience confirms the doubts of sceptics such as McKay $(2013,2014)$, who suggests that SIBs require risk mitigation mechanisms that enable private risks to be placed back on public and third-party actors, or at least shared with them, hence lowering investor risk by raising public liabilities. This more complicated picture could be seen in the New York City (Rikers Island) SIB, mentioned above. This relied on a substantial loan guarantee by a third party, Bloomberg Philanthropies, to absorb three quarters of Goldman Sachs' capital investment (Warner, 2013). Well-established forms of 'entrepreneurial governance' have long sought to incentivise private investment through tax benefits and other mechanisms as a means of economic growth. According to the Treasury, Social Investment Tax Relief, instituted in 2014, was part of such a 'fiscally neutral' growth initiative (HM Treasury, 2013: 48). We contend that SIBs remain largely within the tradition of 'financializing urban governance' (Lake, 2015), by attracting private investment through financial incentives, rather than generating public revenue through taxation.

The social impact bond has been promoted (in part) as a response to a fiscal problem. But there is a fiscal problem at the heart of the SIB itself, which has now forced a further institutional response by the UK government. In 2013, the Cabinet Office committed $£ 20$ million to a Social Outcomes Fund and the Big Lottery Fund formed the $£ 40$ million Commissioning Better Outcomes fund in order to 'top up' investors' outcome payments (Centre for Social Impact Bonds, 2013). Since 2002, more than $£ 1$ billion in subsidies have been committed supporting the UK's social investment market, with the majority of these funds concentrated in the period since the financial crash (Floyd, 2017). These developments appear to confirm the fear of one commentator, that investors only temporarily bring in new resources to the social sector; in the long term they will mostly absorb public money in a zero-sum game. The commentator warns:

[U]nless investors ultimately assume significant outcome performance risk, [pay-for-success] financing may simply cannibalize philanthropic and public funding and fail to increase the capital available to fund the needed interventions. (Godeke, 2013, p. 73). 
While this might fulfil the growth-driven nature of capitalist enterprises and investors, it appears to break the fiscal promise of social investment.

\section{The crisis of capital accumulation}

Since 2008 we have been experiencing what McNally (2009) has called a 'global slump', as the financial crisis has spread into the so-called real economy. As Harvey (2010: 45) explains, the root of this crisis is the over-accumulation of capital, which does not have enough opportunities for its profitable investment and expansion. Just as the discourse around the social investment market - and the rationale for its accelerated development post-2008 - has shifted to accommodate not only social issues, but also fiscal ones, so it now too addresses concerns around economic growth - or capital accumulation. We see social investment as part of a strategy that responds to this over-accumulation crisis. Social investment promises to ameliorate the crisis by opening new investment opportunities for surplus capital.

A second part of this crisis management strategy is 'ethical' - and this anticipates our exploration of capitalism's legitimation crisis in the next section. The social investment market enthusiasts are interested not only in the quantitative expansion of the economy but also with a qualitative shift towards 'inclusive growth'. Thus A. Fraser et al. (2018: 10 \& 8) refer to SIBs' 'financial sector reform narrative' as a way to offset 'the anti-social, dangerous aspects of financial capitalism'. Announcing a 'new paradigm', the G8's Social Impact Investment Taskforce (2014: 1 \& 6) asserts that 'there is no inevitable trade-off between financial and social return': in a non-zero-sum game, 'shared value' can be created with 'blended returns' for financial investors and society alike; SIBs are expected to 'deliver inclusive economic growth that benefits everyone'. The promise here then is double: SIBs can deliver quantitative growth, but also a qualitative shift in the nature of that growth that works against the uneven development of the capitalist economy, that helps us 'move towards a different capitalism, an ethical one' (OECD, 2010). We evaluate the two issues in turn.

McNally's prediction a decade ago that 'we are very far from the endpoint' (2009: 40), has been borne out by successive 'weak' or 'modest' global growth figures and a serious of gloomy forecasts by bodies such as the International Monetary Fund. In its most recent (at time of writing) World Economic Outlook report, for instance, the IMF (2018: xiv) laments that 'the outlook is one of less balanced and more tentative expansion that we hoped for. ... At the global level, recent data show weakening in trade, manufacturing, and investment. Overall, world economic growth is still solid compared with earlier this decade, but it appears to have plateaued'. Such fragility and turbulence has, of course, translated into lower returns and greater risks in bond and equity markets (see, e.g. IMF 2017), with one recent report warning that '[a] new era of lower returns punctuated by frequent volatility threatens to become the "new normal"' (Greenhalgh, 2016).

Enter social impact bonds. We have already noted that one of architects of the Peterborough SIB predicted it would offer 'excellent returns on investment', while the authors of the G8's report on impact investment suggested social investment instruments have the potential to provide 'a new set of attractive investment opportunities'. Others have made similar promises and predictions. In 2010, for instance, a J.P. Morgan report defined impact investments as 'an emerging asset class'. Suggesting that 'the market opportunity is vast', this report's authors also noted that 'some investors expect returns that compete with, and even outperform, traditional investment benchmarks' (O'Donohoe et al., 2010: 11 \& 31; our emphasis). In its typology of potential social investors, Big Society Capital (nd: 19-20) makes clear that at least some categories of investor will seek both 'security of capital [... and] competitive [rates of 
return]'. Big Society Capital itself 'will make investments with risk and return characteristics comparable to the broader financial market' (Schwab Foundation for Social Entrepreneurship 2013: 26).

We should not be surprised that social investors desire and are being promised a financial return - after all, an oft-repeated strapline of social finance is doing well by doing good. But what is interesting is the possibility, suggested by Dowling and Harvie (2014), that social investment might involve not only a harnessing of the financial in order to do good, that is, to tackle deepseated social problems, but also a harnessing of the social to do well, that is, to help tackle the deep-seated problems of the global economy in the wake of the global financial crisis.

As we explained above, the project funded by the Peterborough SIB met the predetermined threshold reduction in reconviction events and thus a one-off payment to investors was made. This represented investors' 'initial capital plus an amount that will represent a return of just over 3\% per annum for the period of investment' (Social Finance 2017). This figure is surprisingly low: returns for this bond were promised to be higher, with Social Finance estimating an internal rate of return of 7.5-13\% (Tverin 2014: 8). By way of comparison, analysts are warning that 'low returns' will be the 'new norm': Greenhalgh (2016) expects equity returns of 3-5\%, for example; McKinsey predicts $4-6.5 \%$ for the US over the next 20 years, and 5-6\% in Europe (Authers, 2016). Against this, investors in the Peterborough SIB have not done so well.

The Peterborough bond was the world's first SIB, but it was not the first SIB to make a payment to investors. This honour goes to the Teens \& Toddlers and Adviza/Energize SIBs, set up in 2012 to fund programmes supporting young people at risk of becoming 'NEETs' (not in education, employment or training). Both projects 'performed above expectations and delivered outcomes sufficient to return investor capital earlier than expected' (Social Finance, 2015); according to the final report, 'investors received their initial capital in full, plus a return' - but we have not been able to discover exactly what this return was (Social Finance, 2016: 14). More information is available on the London Homelessness bond, thanks to the research of Cooper et al. (2016), but this information is not precise: according to two of their sources, 'investors are paid $6.5 \%$ annual interest rate... with the principle sum repaid at the end of the contract once all potential sustained outcomes have been achieved'; other interviewees 'disputed this interest rate ... [claiming] the interest rate on the SIB would have to be "very high" ... at least $12 \%$.

The question of SIBs' financial returns - and therefore the extent to which social investment might fulfil its promise of helping address the crisis of capital accumulation - is a matter of both uncertainty and tension. It would seem that the London Homelessness bond has performed relatively well (whether the rate of return is $6.5 \%$ or $12 \%$ ); the Peterborough SIB has underperformed relative to the promise. In the face of risk-return profiles that commercial investors deem 'inappropriate' - i.e. too much risk, too little return - Berndt and Wirth (2018: $31 \& 32$ ) suggest that "[t]here is tremendous pressure for higher potential returns to reflect the higher risks involved', but also claim that

return rates are not nearly as low as we are made to believe. In the UK, institutions such as Big Society Capital expect return rates between 3\% and 5\% ... in some UK SIBs, investor returns can be as high as $12 \%$ or $13 \%$... In sum, in a marked contrast to the widespread representation of SIBs as high-risk investments with only moderate returns, institutional investors are offered something very different: a relatively safe investment with yields that are not unsubstantial in the current moment of stubbornly low interest rates. 
The uncertainty arises because Berndt and Wirth (and other authors) appear to draw their conclusions on the basis of claims made by social-investor 'boosters' (Big Society Capital or Social Finance, for instance, or representatives of the UK's Cabinet Office) before any SIB project had been completed. But, as we and scholars such as Cooper et al., with their two alternative figures for the London Homelessness SIB, have discovered, obtaining rates of return for actually existing social impact bonds - either in process or completed - is quite challenging.

Rates of return are a matter of tension because determining a risk-return profile is not merely a technical exercise. It involves decisions concerning who will bear the material risk - besides service users, of course - of a social intervention failing to achieve its target. Financial investors, as SIBs' designers seemed to intend? Philanthropic social investors, acting as a 'protective shield' in order to help make 'income streams for investment banks as predictable as possible'? (Berndt and Wirth 2018: 31) Service providers? Or the state? And, equivalently, it involves decisions concerning who will be rewarded for taking on risk.

In fact, we find that the profitable outcomes for the investors in the Peterborough case did not deliver the promised 'shared value' with society. Instead, they reflect an uneven development in which public wealth transferred into private hands in a zero-sum game, an example of what the Midnight Notes Collective (1990) called 'new enclosures' and Harvey (2005) 'accumulation by dispossession'. This is because investor returns were not paid from new savings but from new public expenditure growth and from Big Lottery revenues, as described in the previous section. In fact, an important part of the wealth used as subsidies to 'top up' investor returns originates from society's lower economic strata in a process of upward redistribution. We argue that this can be traced by following the financial flows, reconstructed here. Whereas the Ministry of Justice's budget is part of wider state spending, financed by government borrowing, taxation and so on, the National Lottery derives its income from sales of lottery tickets, which are disproportionately purchased by low-income individuals (Beckert and Lutter, 2013). Moreover, a source of much of the initial capital for Big Society Capital, the UK's social investment wholesale bank, were unclaimed assets from 'dormant' bank and building society accounts (King, 2010; HM Treasury, 2014). According to the Financial Times, the average sum of an unclaimed personal deposit 'is less than $£ 100$ ' (Warwick-Ching, 2018).

The SIB promises to create 'shared value'. But, accepting the assumption that it is lowerincome individuals who are more likely to purchase lottery tickets and to leave deposits of less than $£ 100$, it might seem that it is these individuals who are doing more of the sharing, subsidising social-investor profits. In the case of the Peterborough SIB, the investors and thus the recipients of these transfers were charitable trusts and foundations. We believe they will become even more questionable if and when mainstream financial institutions, seeking 'competitive rates of return', begin investing in social impact bonds. Certainly, the practice is unlikely to reduce the perception, shared by $64 \%$ of respondents in the UK in 2015 , that 'the rich get richer and the poor get poorer in capitalist economies' (Montgomerie, 2015).

\section{Capitalism's legitimacy crisis}

\section{In 2017 the Financial Times editorialised:}

Capitalism invites crisis and brings wrenching changes. The pre-crisis failures of leadership, prescience, and stewardship were real. All the same, open capitalism is the only way forward and it requires leadership that acknowledges hard choices, rather than selling easy outrage. The financial crisis is over. The crisis of legitimacy goes on (FT View, 2017; our emphasis). 
Evidence for a legitimation crisis is provided by survey data. Two large global polls in 2009 and 2012, for instance, found little faith in free-market capitalism: half of all respondents agreed that more regulation and reform is required; significant minorities in many countries believing 'free market capitalism is fatally flawed - a different economic system is needed' (BBC World Service, 2009, 2012). Although a 2015 survey found people to have more faith in 'free enterprise' than government to 'lift people out of poverty', significant majorities nevertheless agreed that 'most of the biggest businesses in the world have dodged taxes, damaged the environment or bought special favours from politicians' and that 'economic benefits and burdens' in their countries have been shared 'not very fairly' or 'not at all fairly' (Montgomerie, 2015). In 2016, a Harvard University survey of young US American adults found 51\% rejecting capitalism (Ehrenfreund, 2016). We also see evidence in the weakening support for established political parties or their polarisation both towards the left and the right: in the UK, the Brexit referendum result in 2016 and the emergence of a new leadership in the Labour party, centred around Jeremy Corbyn; in the US, Donald Trump's spectacular presidential election victory in the same year, along with Bernie Sanders's challenge to the 'third-way' democrats around Hillary Clinton.

Against this background, it has become common in both popular and political economy literature to 'identify the zombie as a metaphor appropriate to the socioeconomic present' (Dale, 2012: 19). For Peck et al. (2010: 112), for instance,

\begin{abstract}
[Neoliberalism] may indeed be about to enter a post-programmatic or 'living dead' phase, in which residual neoliberal impulses are sustained not by intellectual and moral leadership, or even by hegemonic force, but by underlying macroeconomic and macroinstitutional conditions - including excess capacity and overaccumulation at the world scale, enforced public austerity and global indebtedness, and growthchasing, beggar-thy-neighbor modes of governance.
\end{abstract}

Neoliberalism is said to be 'dominant but dead' (Smith 2008).

The social investment market is thus coming of age, and being aggressively promoted, in a transformed socio-cultural environment, in which neoliberal hegemony is unstable. In fact, social impact bonds can be understood as a response to hegemonic fragility, though as we argue, we believe the intervention is primarily symbolic, aimed at restoring consent to a modified form of market rule, rather than enabling a substantive shift towards a 'new paradigm'. As Ogman (2018a) elaborates, this involves the recuperation of political alternatives, the selective integration of some of their ideas, as a means of preventing a progressive post-neoliberal alternative from arising, and hence an effort to produce popular consent for a deeply uneven form of market rule; in fact, innovations like the SIB might be harnessed as source of neoliberalism's renewal, in a form of 'roiling' neoliberalism (Peck, 2012: 24-25).

A key protagonist here is The Economist, which, along with other newspapers such as the Financial Times and Washington Post, insists that politicians 'make the case for capitalism' and itself promotes discussion on 'fixing the flaws in today's capitalism' (Economist, 2018). Two of its editors, Andrew Palmer and Matthew Bishop, along with Michael Green, a former Economist journalist, provide some of the strongest evidence for our argument.

For Palmer (2015) the drop in public support for market-centred policies is of clear concern. Acknowledging the "profound shift in public attitudes toward Wall Street that followed the 2008 financial crisis', he nevertheless criticises even moderate efforts to reform the financial sector, suggesting that the 'pendulum [has] swung too far in the opposite direction'. Instead of re-embedding the economy (Polanyi), he favours 'financial innovation', arguing such 'creativity' could be used to make finance 'help everyone-not just the rich'. For Palmer, '[i]nnovative financiers' are not only enriching themselves, but 'are currently helping solve an 
array of socioeconomic problems'. Social impact bonds, for their part, are an 'extremely promising avenue to explore', and the Peterborough project is at the forefront of these developments.

Bishop and Green similarly accentuate the political-strategic dimension of social investment, which operates at a higher scale than the spatial specificity of local projects. They imply that while such projects necessarily have material consequences that are strictly limited in geographical space, they can nevertheless have a much broader impact in shaping public attitudes, in effect limiting the critics and opponents of 'business as usual'. Warning of 'a politically driven squeeze on wealth', Bishop and Green (2015: 128) frame 'philanthrocapitalism' as a means of 'reduc[ing] that risk for the rich'. The threat Bishop and Green detect is that the legitimacy crisis of 'trickle-down' economics might develop into a concerted effort to address inequalities through the redistribution of social wealth - the restoration of 'punitive rates of taxation on the very wealthy' (ibid.), for instance. The waves of counter-neoliberal social movements since the end of 2010 makes this threat more concrete. In the context of a turbulent political environment, Bishop (2012) situates social investment strategies as part of a revised 'contract for the one percent', designed to protect the latter. He notes that 'high hopes' have been expressed about impact investing and predicts that ' $[\mathrm{t}] \mathrm{he}$ investment product that may produce a breakthrough is the social-impact bond'. 'Some quick wins for the new philanthropists would', he contends, 'also take some of the heat out of the growing anti-rich sentiment around the world'.

From this perspective, social investment appears less as a form of modernisation, and more as a rear-guard defence of enormous wealth inequalities, in which 'large differences in personal wealth [might be] tolerated if the rich make a serious effort to give generously and effectively' (Bishop, 2012). Moreover, as we've seen in the Peterborough case, claims of 'effectiveness' elide the deeply uneven material outcomes of policy practices. We cannot empirically test social investment's promise of responding to capitalism's legitimacy crisis - certainly not the impact of a single project such as the Peterborough SIB on broader public attitudes. But, to draw on a point we made at the end of the last section, the 'topping up' of investor dividends by lotteryticket buyers and the untraceable owners of bank accounts containing balances of 'less than $£ 100$ ' would not count as evidence of a 'serious effort [by the rich] to give generously and effectively'.

\section{Conclusion}

We have argued that neoliberalism's crisis and the social investment market's rapid expansion over the past decade represent more than a historical convergence, but rather stand in a causal relationship. We contend that the social impact bond, the financial instrument at the centre of the social investment market, can be understood as part of a 'crisis management strategy'. As such it promises to respond to, or alleviate, four aspects of the multi-faceted crisis: (i) the crisis of social reproduction; (ii) the 'fiscal crisis of the state'; (iii) the crisis of capital accumulation; and, (iv) a crisis of legitimacy of neoliberalism and even of capitalism itself. Of course, the entire project cannot be judged on the basis of a single instance, particularly not the world's first social impact bond. But our assessment of the Peterborough SIB, along with evidence from other SIBs, suggests that it has not delivered on these promises.

First, in terms of 'entrenched' social problems, a symptom of the crisis of social reproduction, the Peterborough project did reduce rates of reoffending. However, given that the Peterborough probation scheme was being compared with 'control groups' for whom there was no probation service, this is hardly a striking result. Moreover, the 'innovations' involved in the scheme were 
modest and could quite easily have been adopted under traditional funding models. In this instance, the social-investment model also crowds out more robust proposals for structural reform which could get at the roots of incarceration. Second, despite the project's success in reducing recidivism, it has rather deepened rather than relieved the state's fiscal crisis: since the project generated no cashable savings, the state and quasi-state bodies (e.g., the National Lottery) have been required to subsidise investor returns, increasing public risk in these publicprivate-partnerships. Third, although the Peterborough SIB provided a new investment opportunity for surplus capital, it did so at the expense of the public, rather than by producing 'shared value'. Since investor returns were 'topped up' by the state, we have instance of upward redistribution of resources, of 'money flowing uphill'. This curious anomaly takes us the SIB's fourth and final promise. Here our argument was that the idea of social investment as a 'new social contract' is more a symbolic than a material intervention: it seeks to reproduce popular consent for a highly unequal social order, rather than achieve a substantive 'paradigm shift' towards 'inclusive growth'. As such, we doubt social investment will help resolve any ongoing crisis of legitimacy.

The Peterborough SIB is just one of many similar bonds in operation worldwide. We must therefore exercise caution in extrapolating from our conclusions. It is encouraging to see that scholars are now subjecting the social investment market to the serious critical scrutiny it warrants - we mentioned some of this critical literature in an earlier section - and we look forward to more studies that consider other SIBs in their geographical and social specificities. But we should not be too cautious. Critical scholars have perhaps been a little slow off the mark in analysing social investment and we have therefore allowed too many of the boosters' claims - hubris even - to go unchallenged for too long. If our interpretation is correct then at least some of the social investment market's enthusiasts see in it an opportunity not to mend something that neoliberalism has broken, but to renew neoliberalism (see also Harvie, 2019) to not 'let a serious crisis go to waste' (Mirowski, 2013). In such a situation, critical scholars must not only produce serious critical scholarship, they/we must also meet and match the social investment market's enthusiasts' political determination. Our focus here has been one specific SIB: we think we have demonstrated that its promises have been broken. Our guess is that what the social investment market and SIBs in general promise is too good to be true.

\section{References}

Alcock P (2012) The Big Society: a new policy environment for the third sector? June 2012, Birmingham: Third Sector Research Centre. At http://www.birmingham.ac.uk/generic/tsrc/documents/tsrc/working-papers/workingpaper-82.pdf

Alcock P and May M (2014) Social Policy in Britain. Palgrave: New York.

Alston P (2018) Statement on Visit to the United Kingdom. United Nations Human Rights, Office of the High Commissioner. London, 16 November. At https://www.ohchr.org/Documents/Issues/Poverty/EOM_GB 16Nov2018.pdf [accessed 14.12.18].

Anders J and Dorsett R (2017) HMP Peterborough Social Impact Bond - cohort 2 and final cohort impact evaluation, 11 June, London: National Institute of Social and Economic Research. At https://assets.publishing.service.gov.uk/government/uploads/system/uploads/attachment_d ata/file/633243/peterborough-social-impact-bond-cohort-2-results-report.pdf. 
Authers J (2016) Stock markets' 30-year sweetspot under serious threat. Financial Times, 29 April.

BBC World Service (2009) Wide Dissatisfaction with Capitalism - Twenty Years after Fall of Berlin Wall, 9 November. At http://www.worldpublicopinion.org/pipa/pdf/nov09/BBCBerlinWallNov09rpt.pdf

BBC World Service (2012) Economic System Seen as Unfair: Global Poll, 25 April. At http://www.globescan.com/images/images/pressreleases/bbc2012economics/BBC12Econo mics.pdf

Barbagallo C and Federici S (2012) eds. "Care Work" and the Commons. Special issue of The Commoner (issue 15). At www.thecommoner.org.

Beckert J and Lutter M (2013) Why the Poor Play the Lottery: Sociological Approaches to Explaining Class-Based Lottery Play. Sociology 47(6): 1152-70.

Berndt C and Wirth M (2018) Market, metrics, morals: The Social Impact Bond as an emerging social policy instrument. Geoforum 90: 27-35.

Big Society Capital (ND) Big Society Capital: Vision, Mission and Activities. London: Big Society Capital. At http://www.bigsocietycapital.com/sites/ default/files/pdf/BSC\%20Vision,\%20mission\%20and\%20activities.pdf

Bishop M (2012) Good Business? The Future of Philanthropy. The Economist 21.11.2012. At http://www.economist.com/news/21566437-future-philanthropy-good-business [accessed 09.05.2016].

Bishop M and Green M (2015) Philanthrocapitalism comes of age. In: Nicholls A, Emerson J and Paton R (eds) Social Finance. Oxford: Oxford University Press: pp. 113-29.

Boyer WW (1990) Political Science and the 21st Century: From Government to Governance, PS: Political Science and Politics 23 (1): 50-54.

Brand U (2013) State, context and correspondence. Contours of a historical-materialist policy analysis. Österreichische Zeitschrift für Politikwissenschaft, 42(4): 425-442.

Brown G(ordon) (2017). Social Impact Investment Just Paid Off. Project Syndicate 31 July. At: https://www.project-syndicate.org/commentary/peterborough-social-impact-bondspay-off-by-gordon-brown-2017-07

Brown G(areth), Dowling E, Harvie D \& Milburn K (2013) Careless talk: social reproduction and fault-lines of the crisis in the UK. Social Justice: A Journal of Crime, Conflict and World Order 39(1): 68-85.

Burmester M and Wohlfahrt N (2015) The Social Impact Bond - solving social problems with impact-orientation in the investment in social services? Presented at 'The Ethical Turn in Finance?', Leicester UK, 17 September.

Cabinet Office, HM Revenue \& Customs, \& HM Treasury (2015) Social investment tax relief. 27 March 2015. At https://www.gov.uk/government/publications/social-investmenttax-relief-factsheet/social-investment-tax-relief

Callanan L, Law J and Mendonca L (2012) From Potential to Action. Bringing Social Impact Bonds to the U.S. McKinsey \& Company.

Candeias M (2011) Passive Revolutions vs. Socialist Transformation. Background paper for the Commons-Conference in Rome, 28/29 April 2011, organised by Rosa Luxemburg Foundation Brussels. 
Cave S et al. (2012) Peterborough Social Impact Bond: an independent assessment.

Development of the PSM methodology, London: Ministry of Justice. At

http://socialwelfare.bl.uk/subject-areas/services-client-groups/adult-

offenders/ministryofjustice/137159peterborough-social-impact-bond-assessment.pdf Last accessed 12.05.2016.

Centre for Social Impact Bonds (2013) Big Lottery Fund Support, 17 September. At http://data.gov.uk/sib_knowledge_box/big-lottery-fund-support.

Centre for Social Impact Bonds (nd) Social Impact Bonds. At https://data.gov.uk/sibknowledgebox/social-impact-bonds-sibs; last accessed 24.05.2016.

Cooper C, Graham C and Himick D (2016) Social impact bonds: The securitization of the homeless. Accounting, Organizations and Society 55(C): 63-82.

Crouch, C (2006) 'Modelling the Firm in its Market and Organizational Environment: Methodologies for Studying Corporate Social Responsibility'. Organization Studies, 27(10): 1533-1551.

Dagdeviren H, Donoghue M and Promberger M (2016) Resilience, Hardship and Social Conditions. Journal of Social Policy 45(1): 1-20.

Dale G (2012) Double movements and pendular forces: Polanyian perspectives on the neoliberal age. Current Sociology 60(1), 3-27.

Dalla Costa M and Dalla Costa G (1999) eds Women, Development, and Labor of Reproduction: Struggles and Movements. Trenton, NJ: Africa World Press.

Davies JS and Blanco I (2017) Austerity urbanism: Patterns of neo-liberalisation and resistance in six cities of Spain and the UK. Environment and Planning A 49(7), 1517 1536 .

Disley E and Rubin J (2014) Phase 2 report from the payment by results Social Impact Bond pilot at HMP Peterborough. London: Ministry of Justice.

Disley E et al. (2011) Lessons Learned from the Planning and Early Implementation of the Social Impact Bond at HMP Peterborough, Research Series 5/11, Rand Europe and Ministry of Justice. At http://socialwelfare.bl.uk/subject-areas/services-clientgroups/adult-offenders/ministryofjustice/125755social-impact-bond-hmppeterborough.pdf.

Disley E et al. (2015) The payment by results Social Impact Bond pilot at HMP Peterborough: final process evaluation report. London: Ministry of Justice. At https://www.gov.uk/government/uploads/system/uploads/attachment_data/file/486512/soc ial-impact-bond-pilot-peterborough-report.pdf.

Dowling E (2017) In the wake of austerity: social impact bonds and the financialisation of the welfare state in Britain. New Political Economy 22(3): 294-310.

Dowling E and Harvie D (2014) Harnessing the social: state, crisis and (big) society). Sociology, 848(5): 869-886.

Economist, The (2017) 'Impact investing' inches from niche to mainstream. 5 January.

Economist, The (2018) Fixing the flaws in today's capitalism. 16 April.

Ehrenfreund M (2016) A majority of millennials now reject capitalism, poll shows. The Washington Post, 26 April. 
Ellis L and Lubin Y (2015) Social Impact Bonds: A unique opportunity to counteract a reduction in public spending in the Youth Justice System. Cambridge: The Wilberforce Society.

Farnsworth K and Irving Z (2015) Austerity: more than the sum of its parts. In: Farnsworth K and Irving Z (eds.) Social Policy in Times of Austerity: Global Economic Crisis and the New Politics of Welfare. Bristol: Policy Press, pp. 9-41.

Floyd D (2017) The First Billion (of Subsidy) - What Next? 25 September 2017. At: https://access-socialinvestment.org.uk/blog/first-billion-subsidy-next/

Fraser A, Tan S, Lagarde M and Mays N (2018) Narratives of Promise, Narratives of Caution: A Review of the Literature on Social Impact Bonds. Social Policy \& Administration 52(1): 4-28.

Fraser N (2016) Contradictions of capital and care. New Left Review, 100 (July-August): 99117.

Friedman, M (1970) The Social Responsibility of Business is to Increase Its Profits. The New York Times 13 September 1970.

FT View (2017) Ten years on, the crisis leaves a dark legacy. Financial Times. 11 August.

Fukuyama F (1992) The End of History and the Last Man. New York: Free Press.

Giddens A (1998) The Third Way: The Renewal of Social Democracy. Cambridge: Polity.

Giddens A (2000) The Third Way and Its Critics. Cambridge: Polity.

Godeke, S. (2013) Community Reinvestment Act (CRA) Banks as Pioneer Investors in Pay for Success Financing. Community Development Innovation Review (April): 69-74. At: https://www.frbsf.org/community-development/files/community-reinvestment-act-bankspioneer-investors-pay-for-success-financing.pdf.

Greenhalgh H (2016) Low returns will be new norm for investors, say wealth managers. Financial Times, 2 February.

Hay C (1999) Crisis and the structural transformation of the state: interrogating the process of change. British Journal of Politics and International Relations 1(3): 317-344.

Harvey D (2003) The new imperialism. Oxford: Oxford University Press.

Harvey D (2010) The Enigma of Capital: And the Crises of Capitalism. London: Profile Books.

Harvie D (2019) (Big) society and (market) discipline: social investment and the financialisation of social reproduction. Forthcoming in Historical Materialism.

Harvie D, Lightfoot G, Lilley S and Weir K (2018) 'Social investment innovation and the "social turn" of neoliberal finance'. Manuscript under review with Critical Perspectives on Accounting.

HM Treasury (2013) Autumn Statement 2013. London HM Treasury. At https:/www.gov.uk/government/uploads/system/uploads/attachment_data/file/263575/Aut umn_Statement_2013.pdf

HM Treasury (2014) Review of the Dormant Bank and Building Society Accounts Act 2008. London: HM Treasury. At https://www.gov.uk/government/publications/review-of-thedormant-bank-and-building-society-accounts-act-2008. 
Horesh R (1988) Social Policy Bonds. In: Agribusiness and Economics Research Unit Lincoln College Canterbury. Discussion Paper 121: 266-80. Available at http://socialgoals.com/SPBsBlenheim.pdf.

Institute for Fiscal Studies (2017) Two parliaments of pain: the UK public finances 2010 to 2017. Briefing note, 2 May. At https://www.ifs.org.uk/publications/9180.

International Monetary Fund (2018) World Economic Outlook: Challenges to Steady Growth, October, Washington, DC: IMF. At:

http://www.imf.org/en/Publications/WEO/Issues/2018/09/24/world-economic-outlookoctober-2018.

International Monetary Fund (2017) Global Financial Stability Report: Getting the Policy Mix Right, April, Washington, DC: IMF. At http://www.imf.org/en/Publications/GFSR/Issues/2017/03/30/global-financial-stabilityreport-april-2017.

Katz C (2001) Vagabond Capitalism and the Necessity of Social Reproduction. Antipode 33(4): 709-728.

King M (2010) Dormant Accounts to Fund 'Big Society' Bank. The Guardian, 19 July. At http://www.theguardian.com/money/2010/jul/19/dormant-accounts-fund-big-society-bank

Konzelmann SJ (2014) The Political Economics of Austerity. Cambridge Journal of Economics 38(4): 701-741.

Lake, RW (2015) The financialization of urban policy in the age of Obama. Journal of Urban Affairs 37(1): 75-78.

Macdonald K (2010) First Social Impact Bond Launched. London: Philanthropy UK.

McHugh N, Sinclair S, Roy M, Huckfield L and Donaldson C (2013) Social impact bonds: a wolf in sheep's clothing? Journal of Poverty and Social Justice 21(3): 247-257.

McKay K (2013) Evaluating Social Impact Bonds as a New Reentry Financing Mechanism: A Case Study on Reentry Programming in Maryland. Annapolis, MD: Bepress. At: https://works.bepress.com/kylemckay/2/

McKay K (2014) Testimony on Social Impact Bonds Before U.S. Senate Task Force on Government Performance. Annapolis, MD: Bepress. At: http://works.bepress.com/kylemckay/6

McNally D (2009) From financial crisis to world-slump: Accumulation, financialisation, and the global slowdown. Historical Materialism 17(2): 35-83.

Midnight Notes Collective (1990) eds. The New Enclosures. Jamaica Plain, MA: Midnight Notes.

Miliband E (2011) Speech on the cost of living crisis facing Britain. New Statesman. 28 February.

Mills, H and Roberts R (2012) Reducing the numbers in custody: looking beyond criminal justice solutions. Centre for Crime and Justice Studies. 23 January 2012. At: https://www.crimeandjustice.org.uk/publications/reducing-numbers-custody-lookingbeyond-criminal-justice-solutions

Ministry of Justice (2010) Scheme launched to reduce reoffending in short term prisoners, Press Release 18 March. At:

http://webarchive.nationalarchives.gov.uk/20100306090523/http:/www.justice.gov.uk/ne ws/newsrelease180310a.htm (accessed 18 April 2016) 
Ministry of Justice (2014) Offenders Released from Peterborough Prison. At: http://data.gov.uk/sib_knowledge_box/ministry-justice-offenders-released-peterboroughprison

Ministry of Justice and Social Finance (2010) Minister Launches Social Impact Bond Pilot. At: http://www.socialfinance.org.uk/sites/default/files/SIB_Launch_PR.pdf

Mirowski P (2013) Never Let a Serious Crisis Go to Waste: How Neoliberalism Survived the Financial Meltdown. London: Verso.

Montgomerie T (2015) What the World Thinks of Capitalism: YouGov's seven nation opinion poll for the Legatum Institute, London: Legatum Institute. At https://social.shorthand.com/montie/3C6iES9yjf/what-the-world-thinks-of-capitalism

New Economics Foundation (2013) Surviving Austerity: Local voices and local action in England's poorest neighbourhoods, London: NEF.

Nicholls A, Emerson J and Paton R (2015) eds. Social Finance. Oxford: Oxford University Press.

Nicholls A and Tomkinson E (2015) The Peterborough Pilot Social Impact Bond. In: Nicholls A, Emerson J and Paton R (eds) Social Finance, Oxford: Oxford University Press, pp. 335-380.

O'Connor J (1973) The Fiscal Crisis of the State. New York: St. Martin's Press.

O'Donohoe N, Leijonhufvud C and Sultut Y (2010) Impact Investments: An emerging asset class. J.P. Morgan, Rockefeller Foundation and Global Impact Investing Network.

OECD (2010) How social entrepreneurship can help us achieve sustainable social progress. 14 June 2010. At: http://www.oecd.org/regional/leed/46432677.pdf

Ogman R (2016) Social Impact Bonds: A 'Social Neoliberal' Response to the Crisis? In: Schipper S and Schönig B (eds) Urban Austerity. Impacts of the Global Financial Crisis on Cities in Europe. Berlin: Theater der Zeit, pp. 58-69.

Ogman R (2018a) 'Ethical Capitalism' in the City. Embedded Economy or Market Subordination? The Case of Social Impact Bonds. Manuscript under review with Journal of Urban Affairs.

Ogman R (2018b) Crisis, Hegemony, and the Social Investment Market. The Cultural Political Economy of an Emerging Governance Strategy. Doctoral thesis, De Montfort University, Leicester, UK.

O’Hara M (2015) Austerity Bites. Bristol: Policy Press.

Palmer A (2015) In Defense of Financial Innovation. Foreign Affairs May/June 2015. At https://www.foreignaffairs.com/articles/united-states/2015-03-05/defense-financialinnovation

Parsons J, Weiss C and Wei Q (2016) Impact Evaluation of the Adolescent Behavioral Learning Experience (ABLE) Program. New York: Vera Institute of Justice. At: https://www.vera.org/publications/rikers-adolescent-behavioral-learning-experienceevaluation

Peck J (2001) Workfare States. New York: Guilford Press.

Peck J (2010) Zombie neoliberalism and the ambidextrous state. Theoretical Criminology 14(1): 104-110.

Peck J (2012) Constructions of Neoliberal Reason. Oxford: Oxford University Press. 
Peck J (2013) Pushing austerity: state failure, municipal bankruptcy and the crises of fiscal federalism in the USA. Cambridge Journal of Regions, Economy and Society 7(1): 17-44.

Peck J, Theodore N and Brenner N. (2010) Postneoliberalism and its malcontents. Antipode 41(s1): 94-116.

Pybus J (2012) Government Fills Funding Gap for UK Social Impact Bonds. Pioneers Post. 23 November. At https://www.pioneerspost.com/news/20121123/government-fillsfunding-gap-uk-social-impact-bonds

Pybus J (2018) 100+ social impact bonds raise \$400m worldwide since 2010 launch. Pioneers Post. 1 Feburary 2018. At https://www.pioneerspost.com/news-views/20180201/100social-impact-bonds-raise-400m-worldwide-2010-launch

Rosenman E (2017) The geographies of social finance: Poverty regulation through the 'invisible heart' of markets. Progress in Human Geography 40(5): 610-628.

Rudd T, Nicoletti E, Minser K and Bonsu J (2013) Financing Promising Evidence-Based Programs. Early Lessons from the New York City Social Impact Bond. New York: MDRC. At: http://www.mdrc.org/publication/financing-promising-evidence-basedprograms

Saltuk Y (2011) Counter(Imp)acting Austerity. J.P. Morgan Social Finance Research, 28 November. At

https://www.jpmorganchase.com/corporate/socialfinance/document/counterimpacting_aus terity.pdf (accessed 12 May 2016)

Schwab Foundation for Social Entrepreneurship (2013) Breaking the Binary: Policy Guide to Scaling Social Innovation. Cologne/Geneva: Schwab Foundation for Social Entrepreneurship. At http://socialenterprise.georgetown.edu /sites/socialenterprise.georgetown.edu/files/Breaking\%20the\%20Binary.pdf

Sinclair S, McHugh N, Huckfield L, Roy M and Donaldson C (2014) Social Impact Bonds: Shifting the Boundaries of Citizenship. In: Farnsworth K, Irving Z and Fenger M (eds) Social Policy Review 26: Analysis and Debate in Social Policy, Bristol: Policy Press, pp. 111-128.

Smith N (2008) Neo-liberalism: Dead but Dominant. Focaal: European Journal of Anthropology 51: 155-157.

Social Finance (2011) Social Impact Bonds: The One Service. One Year On. At: http://www.socialfinance.org.uk/resources/social-finance/social-impact-bonds-oneservice-one-year

Social Finance (2014) Peterborough Social Impact Bond Reduces Reoffending by 8.4\%; Investors on Course for Payment in 2016. At:

https://www.socialfinance.org.uk/sites/default/files/news/peterborough-first-cohortresults.pdf [last accessed 18.06.2018]

Social Finance (2015) The Energize and Teens and Toddlers Programmes 2012-2015, London: Social Finance. At:

https://www.socialfinance.org.uk/sites/default/files/news/press-release-first-social-impactbonds-to-return-investor-capital.pdf [last accessed 18.06.2018]

Social Finance (2016) First Social Impact Bonds to Return Investor Capital, 14 July. At: https://www.socialfinance.org.uk/sites/default/files/news/press-release-first-social-impactbonds-to-return-investor-capital.pdf [last accessed 18.06.2018] 
Social Finance (2017) World's 1st Social Impact Bond shown to cut reoffending and to make impact investors a return. At

https://www.socialfinance.org.uk/sites/default/files/news/final-press-release-pb-july2017.pdf [last accessed 18.06.2018]

Social Impact Investment Taskforce (2014) Impact Investment: The Invisible Heart of Markets. At http://www.socialimpactinvestment.org/reports/Impact\%20Investment\%20Report\%20FIN AL[3].pdf

Steger M and Roy R (2010) Neoliberalism: A Very Short Introduction. Oxford/New York: Oxford University Press.

Sum N-L and Jessop B (2013) Towards a Cultural Political Economy: Putting Culture in its Place in Political Economy. Cheltenham/Northampton: Edward Elgar Press.

Swinford S (2014) The BBC's 'Wigan Pier' analysis which offended David Cameron in full. The Telegraph. 4 December. At https://www.telegraph.co.uk/finance/autumnstatement/11272949/The-BBCs-Wigan-Pier-analysis-which-offended-David-Cameron-infull.html.

Travis A (2010) Will social impact bonds solve society's most intractable problems? The Guardian 6 October 2010. At: http://www.theguardian.com/society/2010/oct/06/socialimpact-bonds-intractable-societal-problems

Tse AE and Warner ME (2018) The razor's edge: social impact bonds and the financialization of early childhood services. Journal of Urban Affairs. DOI: 10.1080/07352166.2018.1465347

Tverin A (2014) Social Impact Bonds: Examples of Targetted Interventions, 12 November, London: Social Finance. At https://media.sitra.fi/2017/02/27051641/annika_tverin_31.pdf [last accessed 18.06.2018]

Warner ME (2013) Private finance for public goods: social impact bonds. Journal of Economic Policy Reform 16(4): 303-319.

Warner ME and Clifton J (2013) Marketisation, public services and the city: the potential for Polanyian counter-movements. Cambridge Journal of Regions, Economy and Society 7(1): 45-61.

Warwick-Ching L (2018) UK government to seize millions of pounds from dormant bank accounts. Financial Times 4 January.

Wiggan J (2018) Policy boostering the social impact investment market in the UK. Journal of Social Policy 47(4): 721-738.

Williams A, Goodwin M and Cloke P (2014) Neoliberalism, Big Society, and progressive localism. Environment and Planning A 46(12): 2798-2815.

Wilson R (2015) The future of the UK social investment market. Speech delivered by Rob Wilson, Minister for Civil Society, to Social Investment and Public Services conference, Kensington Town Hall, 20 January. Transcript at:

https://www.gov.uk/government/speeches/social-investment-and-public-servicesconference

World Economic Forum (2013) From the Margins to the Mainstream Assessment of the Impact Investment Sector and Opportunities to Engage Mainstream Investors, September. Geneva: WEF. At:

http://www3.weforum.org/docs/WEF_II_FromMarginsMainstream_Report_2013.pdf 